\title{
ASSESSMENT OF RELATIONSHIP BETWEEN LOCATIONS AND DISTANCES TO ROADSIDE OF FOREST FIRES IN ISTANBUL, TURKEY
}

\author{
SENTURK, N. \\ Department of Forest Construction and Transportation, Faculty of Forestry, Istanbul \\ University-Cerrahpasa, 34473 Bahcekoy, Istanbul, Turkey \\ (e-mail: nsenturk@istanbul.edu.tr) \\ (Received $16^{\text {th }}$ Jul 2018; accepted 22 $2^{\text {nd }}$ Aug 2018)
}

\begin{abstract}
Forest fires have negative effects on human health, ecosystems and climate change. One way to fight and prevent forest fires is formation of risk maps based on Geographical Information Systems (GIS). This study created a GIS-based database that contains information on forest fires that took place in Istanbul, Turkey in the period of 2013-2016 such as location, reason, burned area, etc. According to the spatial analysis maps that were obtained based on the initial location of the fires in 2013-2016, a large part of the fires took place in the zone in the south of the city between forests and settlement areas. It was also aimed in this study to reveal the relationship between the initial locations of forest fires and their distance to forest roads. For this purpose, spatial and temporal distribution maps were crated for the fires that took place in 2013-2016 with buffer zones that were created in distances of 0-25 m, 25-50 m, 50$75 \mathrm{~m}$ and 75-100 m from forest roads. According to the results of this analysis, among the total of 427 forest fires that took place within $0-100 \mathrm{~m}$ from forest roads, $186(43 \%)$ took place within $0-25 \mathrm{~m}, 99$ (23.19\%) took place within $25-50 \mathrm{~m}, 90(21.08 \%)$ took place within $50-75 \mathrm{~m}$ and $52(12.18 \%)$ took place within 75-100 m. As it may be understood from the analysis results, numbers of fires decrease when the distance from forest roads increases.
\end{abstract}

Keywords: forest road, forest fire, spatial analysis

\section{Introduction}

Forest fires occur due to natural and anthropogenic effects (Adab et al., 2013; Demir et al., 2009) and affect human health, ecosystems and climates negatively (Sukitpaneenit and Oanh, 2014; Arganaraz et al., 2015). In a time less than the last 200 years, about six million square kilometers $(600,000,000 \mathrm{ha})$ of the forests in the world were damaged due to forest fires (Dimopoulou and Giannikos, 2004).

Reducing the severity of losses related to forest fires is largely dependent on precautions such as fire prevention, detection and elimination (Kucuk et al., 2017). One of the most important precautions in question is formation of fire risk maps. Fire risk maps, which are created for determining areas with high fire risk, are a significant prevention tool that will help plan firefighting and fire prevention work (Aricak et al., 2014).

In forming fire risk maps, GIS-based spatial analysis results provide significant basis in fighting fire (Jaiswal et al., 2002; Erten et al., 2004).

Based on their cause of occurrence, forest fires may be divided into six groups as natural fires, fires with no known cause, accident fires, deliberate fires, voluntary fires and rekindle fires (San-Miguel-Ayanz et al., 2012). The FAO report dated 1998 stated that the vast majority of the fires in Turkey were anthropogenic. While the ratio of anthropogenic fires in Turkey is $97 \%$, only 3\% occurred due to lightning. Among anthropogenic fires, $23 \%$ occur due to arson and deliberation, $27 \%$ occur due to neglect 
and carelessness, and 50\% occur without a known cause (Mol and Kucukosmanoglu, 1997; FAO, 1998).

As Mol and Kucukosmanoglu stated in 1997, people cause the majority of forest fires in Turkey. Again, a significant part of these occurs due to fires that are lit during picnics with recreational purposes. There are areas for building controlled fires in recreational areas.

However, especially in large metropolitan cities where there is intense anthropogenic pressure on forests such as Istanbul, recreational areas may be insufficient, and people may build picnic fires in forests outside controlled picnic areas. The majority of the places where these fires in question are built are near forest roads as they are easily accessed. In addition to all forestry operations, forest roads are also used for recreational needs (Akgul et al., 2016).

In the scope of the study, GIS-based spatial analyses were used to map the fires that took place in the forest areas within the border of the province of Istanbul in the period of 2013-2016 based on the causes of fires and the distances of the fires to forest roads, and the initial locations and intensities of the fires were analyzed.

\section{Material and methods}

\section{Study area}

The research area was selected as Istanbul city which is located in the north-west Marmara region of Turkey, in the coordinates of $28^{\circ} 10^{\prime}$ and $29^{\circ} 40^{\prime}$ East longitudes and $40^{\circ} 50^{\prime}$ and $41^{\circ} 30^{\prime}$ 'North latitudes (Fig. 1).

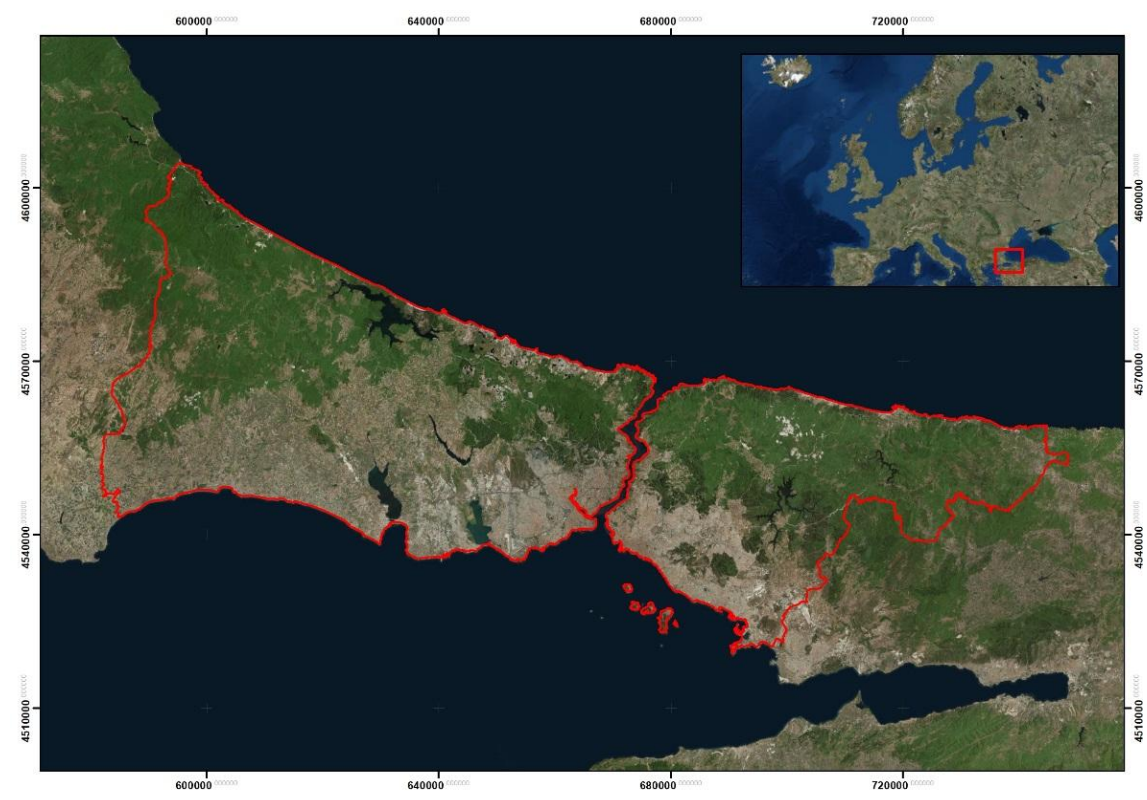

Figure 1. Location map of the study area

About 46.6 (251,716 ha.) of Istanbul is covered with forests, and these areas are distributed in the north of the city. Within the forest areas, there is a total of 4414-kmlong forest roads. There are also 36 recreational areas with different sizes within the forest areas in Istanbul. These areas are popular among the citizens (Fig. 2). 


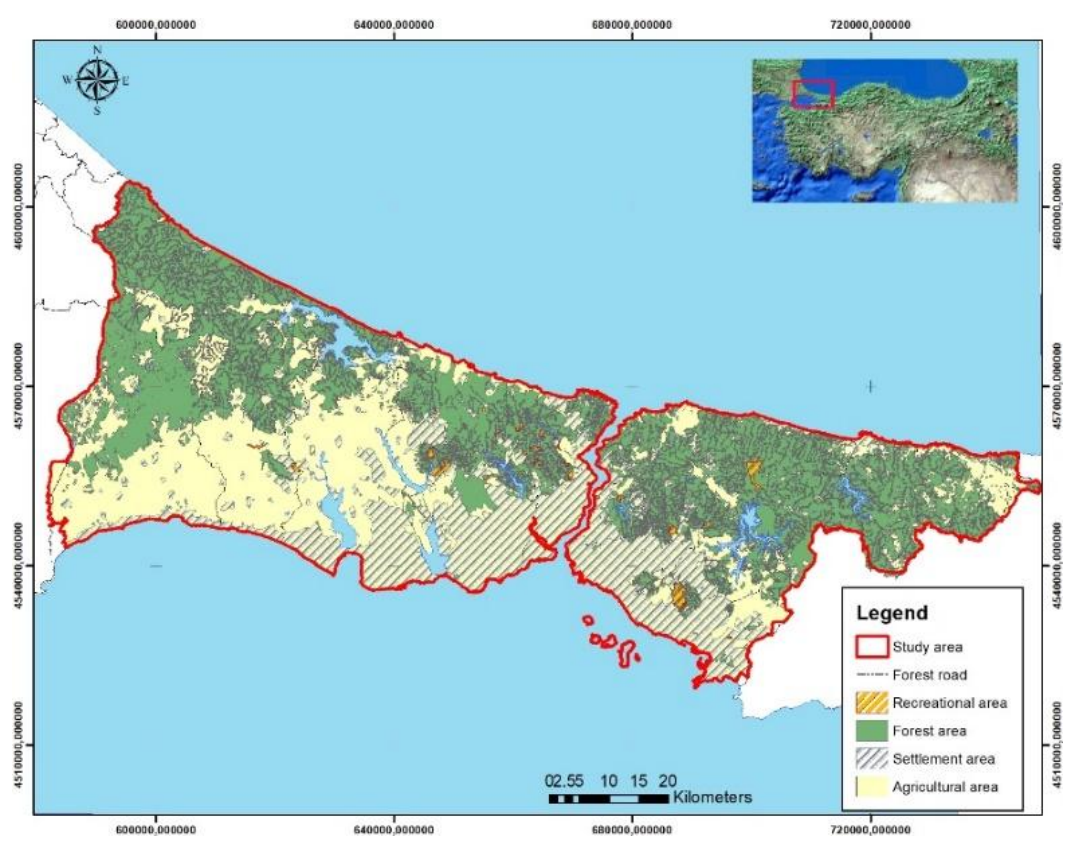

Figure 2. Location map of the study area

\section{Methods}

This study investigated the fires that took place in 2013-2016 in forests within the provincial borders of Istanbul according to General Directorate of Forestry Turkey (GDF, 2017). Where these fires mostly occurred and the distances of these fires were determined. For this, a database was created using the ArcGIS 10.3 GIS software to analyze the locations of these fires. In the database, the date of the forest fires, forest fire occurrence locations (in the ITRF 96 coordinate system), total burnt areas (ha) were defined.

Forest fire density analysis was conducted with the database that was create within the scope of the study. In addition to the density analysis, spatial analysis of the fires that took place in 2013-2016 was carried out using the Kernel Density method. Kernel density method is commonly used in several engineering disciplines it provides to calculates the density of features in a neighborhood around the features.

Within the main purpose of the study buffer zones were defined in distances of 0 $25 \mathrm{~m}, 25-50 \mathrm{~m}, 50-75 \mathrm{~m}$ and $75-100 \mathrm{~m}$ from forest roads. This is how the zone where the fires mostly occurred was determined. The buffer zones were overlapped with the forest fire locations in the ArcGIS 10.3 software. The overlapping process was carried out based on the years.

\section{Results and discussion}

\section{Numerical and spatial distribution of forest fires according to main reason of fires}

In the study, according to fire reasons, forest fires were investigated in five groups as lightning, carelessness, sabotage, electrical fault and unknown cases. In order to determine the relationship between the locations of fire and numbers of fire with fire reasons, the number of fire over the years is also shown in Table 1 depending on the fire reasons. According to spatial distribution analysis results for 2013 it was calculated that 
the minimum number of fire occurred by lightning as one while maximum number of fire caused carelessness was calculated as one.

According to the distribution analysis of main reason of fires (Table 1);

Considering the total of 243 fires that took place in 2013;

- Most (87) of the fires occurred due to carelessness,

- Following this, 78 fires occurred without a known cause,

- The least of the fires (1) occurred due to lightning.

Considering the total of 100 fires that took place in 2014;

- Most (46) of the fires occurred due to carelessness,

- Following this, 28 fires occurred without a known cause,

- The least of the fires (2) occurred due to lightning.

Considering the total of 121 fires that took place in 2015;

- Most (53) of the fires occurred due to carelessness,

- Following this, 45 fires occurred without a known cause,

- The least of the fires (2) occurred due to electrical fault.

Considering the total of 196 fires that took place in 2016;

- Most (141) of the fires occurred due to unknown causes,

- Following this, 38 fires occurred due to carelessness,

- The least of the fires (17) occurred due sabotage.

As understood from the results of the spatial distribution analysis and seen in Figure 4, a large part of the fires took place in the zone in the south of the city between forests and settlement areas. It is also seen that the forest areas and northern parts where forest fires took place the least frequently had high numbers of recreational areas (Fig. 3).

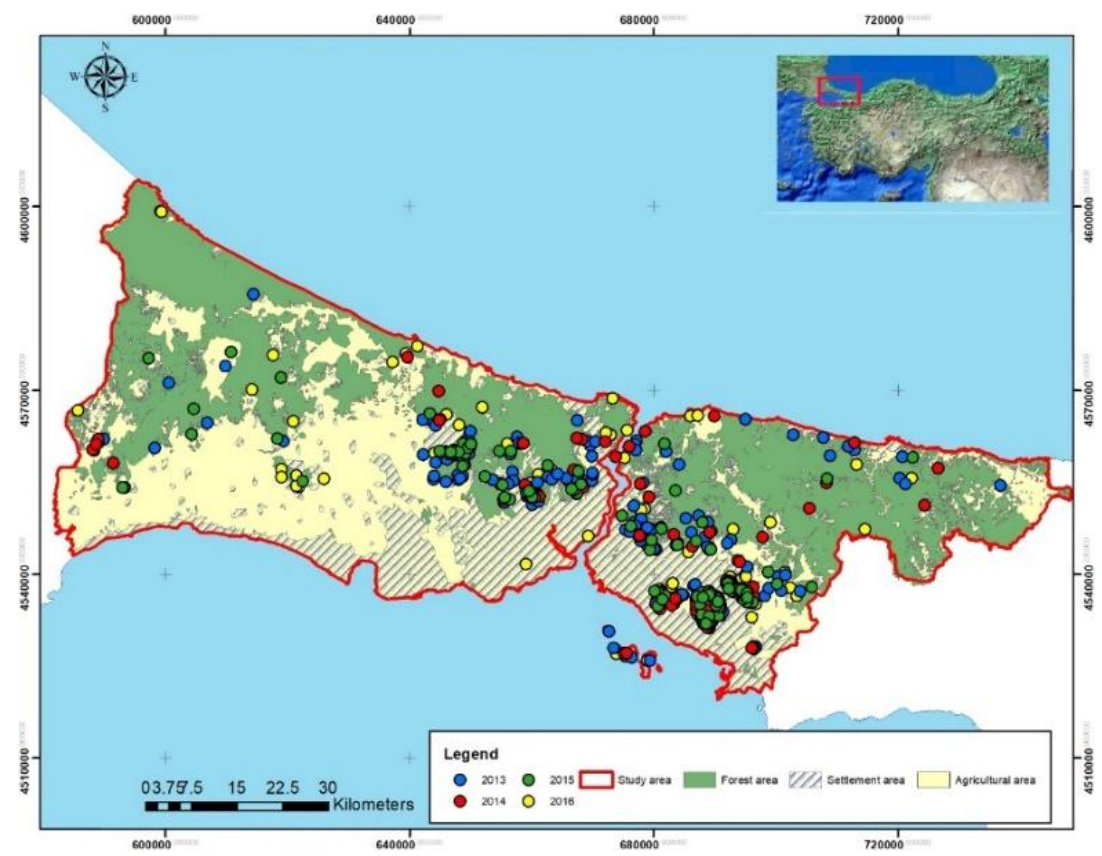

Figure 3. Fire locations by year 
Table 1. Distribution of fires according to main reason of fires

\begin{tabular}{c|c|c|c|c|c}
\hline Fire reason & $\mathbf{2 0 1 3}$ & $\mathbf{2 0 1 4}$ & $\mathbf{2 0 1 5}$ & $\mathbf{2 0 1 6}$ & Total \\
\hline Lightning & 1 & 2 & 0 & 0 & 3 \\
Carelessness & 87 & 46 & 53 & 38 & 224 \\
Sabotage & 72 & 24 & 21 & 17 & 134 \\
Electrical fault etc. & 5 & 0 & 2 & 0 & 7 \\
Unknown cases & 78 & 28 & 45 & 141 & 292 \\
\hline Total & $\mathbf{2 4 3}$ & $\mathbf{1 0 0}$ & $\mathbf{1 2 1}$ & $\mathbf{1 9 6}$ & $\mathbf{6 6 0}$ \\
\hline
\end{tabular}

According to the results of the spatial distribution analysis on the causes of fires;

Within the total of 50.46 ha of burnt areas in 2013;

- The smallest area (0.02 ha) was burnt due to lightning,

- The largest area (26.05 ha) was burnt due to sabotage.

Within the total of 14.13 ha of burnt areas in 2014;

- The smallest area (0.03 ha) was burnt due to lightning,

- The largest area (6.60 ha) was burnt due to carelessness.

Within the total of 24.20 ha of burnt areas in 2015;

- The smallest area (0.09 ha) was burnt due to electrical fault,

- The largest area (9.52 ha) was burnt due to sabotage.

Within the total of 33.78 ha of burnt areas in 2016;

- The smallest area (1.77 ha) was burnt due to sabotage,

- The largest area (28.83 ha) was burnt due to unknown reasons (Table 2, Fig. 4).

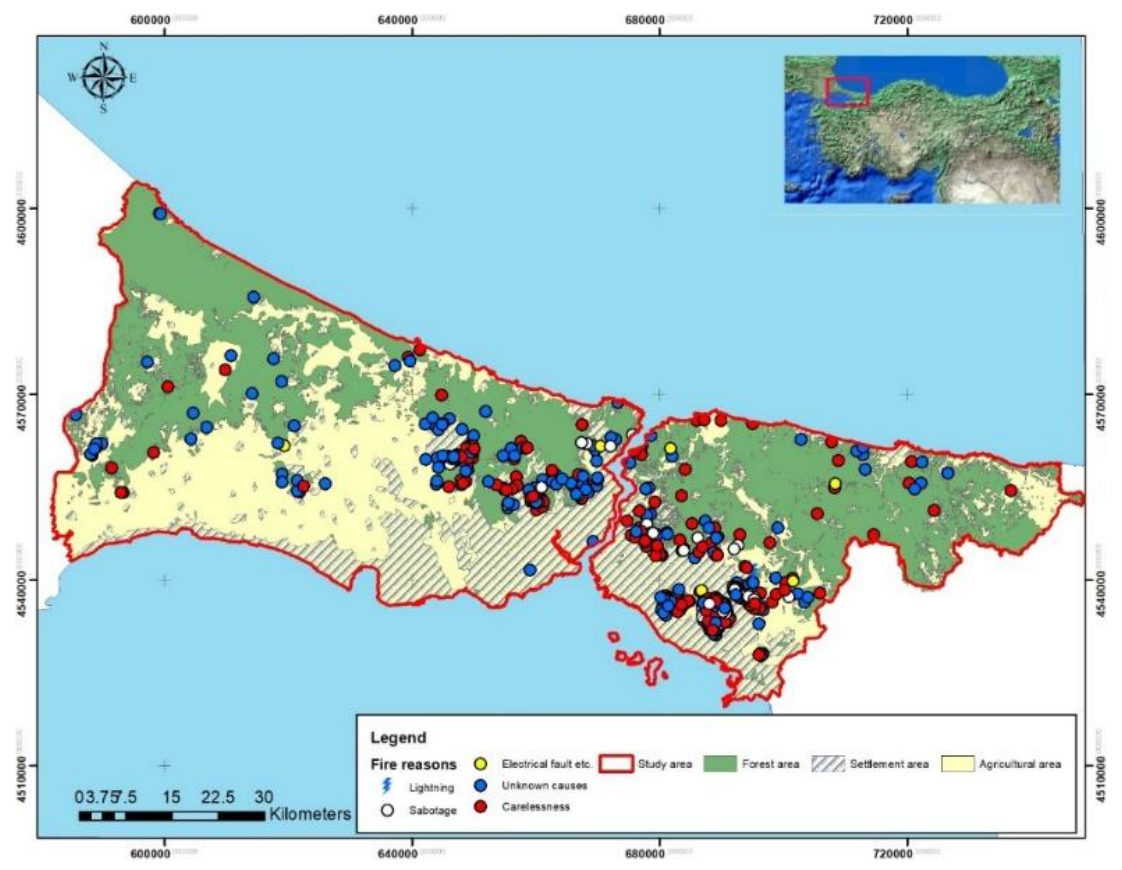

Figure 4. Spatial distribution of forest fires according to fire causes 
Table 2. Distribution of burning areas according to main causes of fires

\begin{tabular}{c|c|c|c|c|c}
\hline Fire reason & $\mathbf{2 0 1 3}$ & $\mathbf{2 0 1 4}$ & $\mathbf{2 0 1 5}$ & $\mathbf{2 0 1 6}$ & Total \\
\hline Lightning & 0.02 & 0.03 & 0 & 0 & 0.05 \\
Carelessness & 8.15 & 6.60 & 9.6 & 3.18 & 27.53 \\
Sabotage & 26.05 & 4.46 & 9.52 & 1.77 & 41.80 \\
Electrical fault etc. & 1.33 & 0 & 0.09 & 0 & 1.42 \\
Unknown cases & 14.91 & 3.044 & 4.99 & 28.83 & 51.77 \\
\hline Total area (ha) & $\mathbf{5 0 . 4 6}$ & $\mathbf{1 4 . 1 3}$ & $\mathbf{2 4 . 2 0}$ & $\mathbf{3 3 . 7 8}$ & $\mathbf{1 2 2 . 5 7}$ \\
\hline
\end{tabular}

\section{Spatial distribution of forest fires by distance to road}

It was aimed to reveal the relationship between the initial locations of the fires and their distance to forest roads. For this purpose, spatial and temporal distribution maps were crated for the fires that took place in 2013-2016 with buffer zones that were created in distances of 0-25 m, 25-50 m, 50-75 m and 75-100 m from forest roads (Fig. 5).

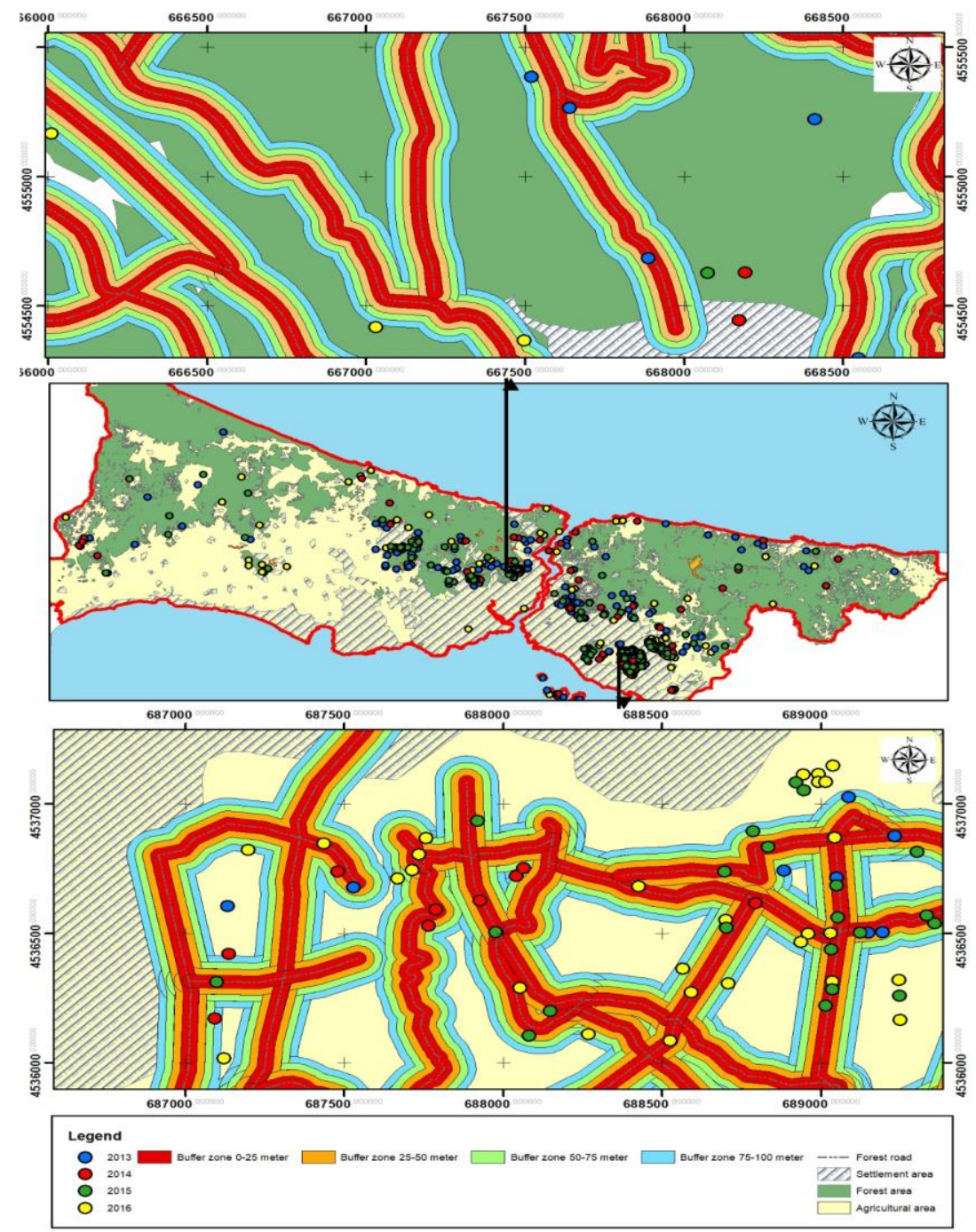

Figure 5. Spatial distribution of forest fires by distance to forest road 
According to the spatial and temporal distribution analysis results, within $100 \mathrm{~m}$ from forest roads, there were

- 197 fires in 2013,

- 42 fires in 2014,

- 76 fires in 2015 ,

- 112 fires in 2016,

constituting a total of 427 fires. This number represents $64.6 \%$ of the total number of fires that took place in Istanbul in 2013-2016 (Table 3, Fig. 6).

Additionally, considering the distances of the fires that occurred in 2013-2016, 186 (43\%) took place within 0-25 m, 99 (23.19\%) took place within 25-50 m, 90 (21.08\%) took place within $50-75 \mathrm{~m}$ and $52(12.18 \%)$ took place within $75-100 \mathrm{~m}$.

In the study by Eskandari (2017) that aimed to reveal forest fire risk using the fuzzy Analytic Hierarchy Process (AHP) and GIS methods, it was found that the distance from the road and the distance from settlements were the most important risk factors among anthropogenic risk factors. Moreover, Narayanaraj and Wimberly (2012) determined that reduction of closure near the roads, increase of wind and temperature and forest management activities impact burning. It was also emphasized by several authors that proximity to roads increases risk of fire (Pourtaghi et al. 2016; Vinod et al., 2016; Ajin et al., 2016).

Table 3. Distribution of forest fires by distance to road

\begin{tabular}{|c|c|c|c|c|c|c|c|c|c|}
\hline \multirow{3}{*}{ Years } & \multicolumn{8}{|c|}{ Buffer zone (m) } & \multirow{3}{*}{ Total } \\
\hline & \multicolumn{2}{|c|}{$0-25 \mathrm{~m}$} & \multicolumn{2}{|c|}{$25-50 \mathrm{~m}$} & \multicolumn{2}{|c|}{$50-75 \mathrm{~m}$} & \multicolumn{2}{|c|}{$75-100 \mathrm{~m}$} & \\
\hline & Number & $\%$ & Number & $\%$ & Number & $\%$ & Number & $\%$ & \\
\hline 2013 & 81 & 41.12 & 48 & 24.37 & 43 & 21.83 & 25 & 12.69 & 197 \\
\hline 2014 & 21 & 50.00 & 6 & 14.29 & 8 & 19.05 & 7 & 16.67 & 42 \\
\hline 2015 & 39 & 51.32 & 18 & 23.68 & 11 & 14.47 & 8 & 10.53 & 76 \\
\hline 2016 & 45 & 40.18 & 27 & 24.11 & 28 & 25.00 & 12 & 10.71 & 112 \\
\hline Total & 186 & 43.56 & 99 & 23.19 & 90 & 21.08 & 52 & 12.18 & 427 \\
\hline
\end{tabular}

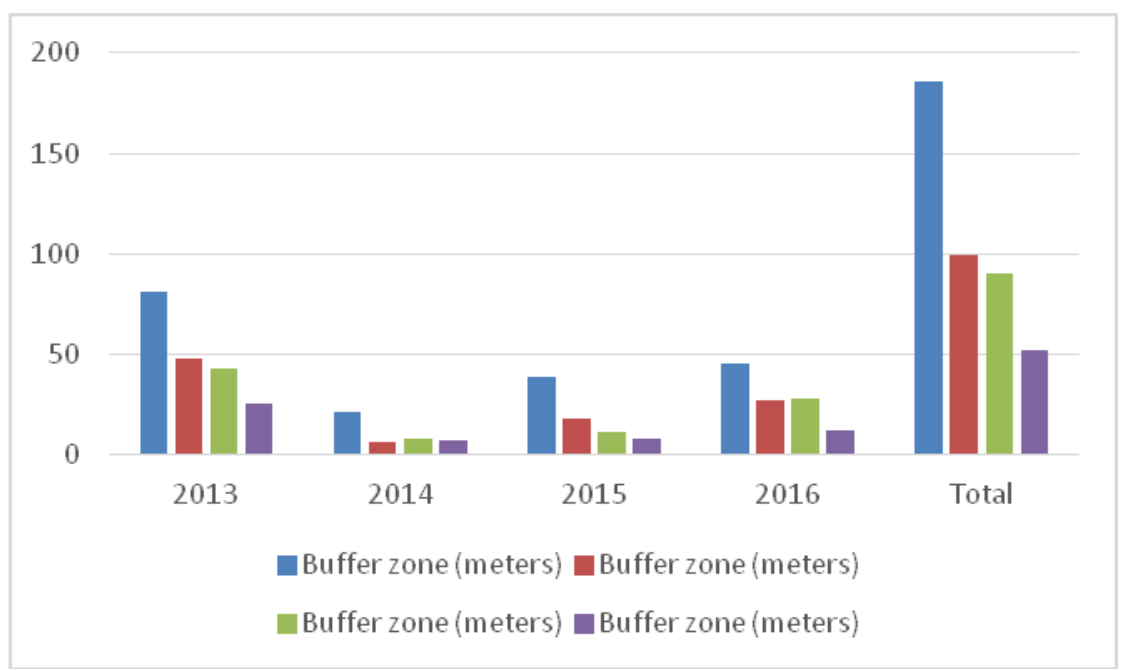

Figure 6. Forest fires by distance to forest road 
As it may be understood from the analysis results, numbers of fires decrease when the distance from forest roads increases. Furthermore, when the ratios of the locations of the fires are considered, it is seen that $97.13 \%$ of the fires in Istanbul occurred in the southern parts of the city. It is understood that most of the fires were found near the settlement areas as can be seen from Figure 4.

This may be interpreted as the following. When the recreational purposes of the citizens in large metropolitan cities like Istanbul and the distance of residential areas to green spaces are considered, the numbers of forest fires are higher in the southern parts of Istanbul where green spaces are lacking. The fire density analysis based on the initial locations of forest fires that is shown in Figure $7 a$ and the area size and fire density analysis that is shown in Figure $7 b$ which were carried out to test this hypothesis also confirmed that the highest density of the forest fires was in the southern parts.
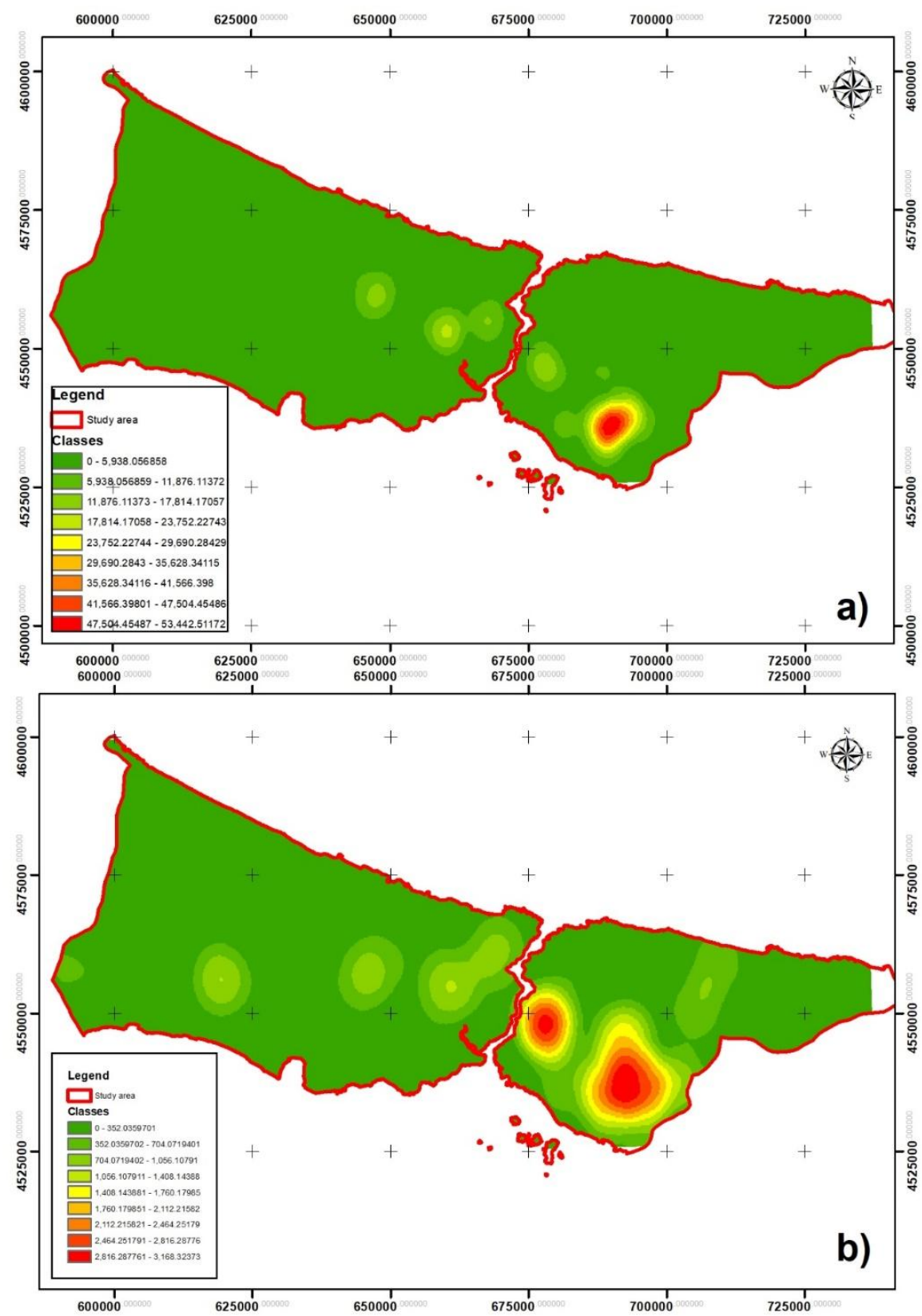

Figure 7. Results of intensity and area fire intensity analysis according to fire exit points 
In agreement with this situation, Dong et al. (2005) stated that as the distance from roads, residential areas and agricultural lands increases, risk of fire would decrease. Moreover, other studies by Suryabgavan et al. (2016) and Matin et al. (2017) observed that forest fires are more frequent in relation to anthropogenic factors in places that are close to residential areas.

Furthermore, considering the distances of the fires from forest roads, in the southern parts of Istanbul where there is a dearth of recreational spaces, it is seen that people park their vehicles on the side of roads and take part in picnic activities with fire due to lacking and/or uncontrolled picnic and recreational needs.

Additionally, the reason for reduced numbers of fires as one gets further away from forest roads may be that people carry out picnic activities with fire at locations close to their vehicles to keep a line of sight for security.

\section{Conclusions}

With this study, the relationship between the locations of fires and their distances to roads and other areas (residential and agricultural land) was determined with the help of GIS. Based on the analyses that were carried out within the scope of the study, it was found that proximity to such locations increased the number of fire. Accordingly, proximity to these places should be kept in mind and planning should involve information on this within the scope of fighting and taking precautions against forest fires. The results of the study are important especially in terms of reducing forest fires that occur due to anthropogenic reasons as people access recreational areas with these roads in large metropolitan cities.

Moreover, it is believed that this study will allow determination of priority and importance of firefighting and precautions against fires, as well as detection and ranking of risk zones. In addition to all these precautions, protective activities in forests and zones between forests and settlements where anthropogenic pressure is high should be carried out intensely, and green spaces (picnic areas and parks) that will reduce the pressure of the citizens on the forest should be planned and built in suitable locations and with suitable space.

\section{REFERENCES}

[1] Adab, H., Kanniah, K. D., Solaimani, K. (2013): Modeling forest fire risk in the northeast of Iran using remote sensing and GIS techniques. - Natural Hazards 65(3): 1723-1743.

[2] Ajin, R. S., Loghin, A. M., Vinod, P. G., Jacob, M. K. (2016): RS and GIS based forest fire risk zone mapping in Periyar Tiger Reserve, Kerala, India. - J. Wetl. Biodivers 6: $175-84$

[3] Akgul, M., Demir, M., Ozturk, T., Topatan, H., Budak, Y. E. (2016): Investigation of recreational vehicles maneuverability on forest roads by computer-aided driving analysis. - Baltic Journal of Road \& Bridge Engineering 11(2): 111-119.

[4] Argañaraz, J. P., Pizarro, G. G., Zak, M., Landi, M. A., Bellis, L. M. (2015): Human and biophysical drivers of fires in Semiarid Chaco mountains of Central Argentina. - Science of the Total Environment 520: 1-12.

[5] Aricak, B., Kucuk, O., Enez, K. (2014): Determination of pumper truck intervention ratios in zones with high fire potential by using geographical information system. Journal of Applied Remote Sensing 8(1): 1-9. 
[6] Demir, M., Küçüksmanoglu, A., Hasdemir, M., Öztürk, T., Acar, H. H. (2009): Assessment of forest roads and firebreaks in Turkey. - African Journal of Biotechnology 8(18): 4553-4561.

[7] Dimopoulou, M., Giannikos, I. (2004): Towards an integrated framework for forest fire control. - European Journal of Operational Research 152(2): 476-486.

[8] Dong, X. U., Li-min, D., Guo-fan, S., Lei, T., Hui, W. (2005): Forest fire risk zone mapping from satellite images and GIS for Baihe Forestry Bureau, Jilin, China. - Journal of Forestry Research 16(3): 169-174.

[9] Erten, E., Kurgun, V., Musaoglu, N. (2004): Forest fire risk zone mapping from satellite imagery and GIS: a case study. - XXth Congress of the International Society for Photogrammetry and Remote Sensing, Istanbul, Turkey, pp. 222-230.

[10] Eskandari, S. (2017): A new approach for forest fire risk modeling using fuzzy AHP and GIS in Hyrcanian forests of Iran. - Arabian Journal of Geosciences 10(8): 190.

[11] FAO (1998): FAO Meeting on Public Policies Affecting Forest Fires. - Proceedings, Rome, 28-30 October 1998.

[12] GDF (2017): Orman yanginlari ile mucadele faaliyet raporu. - Orman Genel Mudurlugu yayinlari, Ankara (in Turkish).

[13] Jaiswal, R. K., Mukherjee, S., Raju, K. D., Saxena, R. (2002): Forest fire risk zone mapping from satellite imagery and GIS. - International Journal of Applied Earth Observation and Geoinformation 4(1): 1-10.

[14] Kucuk, O., Topaloglu, O., Altunel, A. O., Cetin, M. (2017): Visibility analysis of fire lookout towers in the Boyabat State Forest Enterprise in Turkey. - Environmental Monitoring and Assessment 189(7): 329.

[15] Matin, M. A., Chitale, V. S., Murthy, M. S., Uddin, K., Bajracharya, B., Pradhan, S. (2017): Understanding forest fire patterns and risk in Nepal using remote sensing, geographic information system and historical fire data. - International Journal of Wildland Fire 26(4): 276-286.

[16] Mol, T., Kucukosmanoglu, A. (1997): Forest fires in Turkey. - Proceedings of the XIth World Forestry Congress, Antalya.

[17] Narayanaraj, G., Wimberly, M. C. (2012): Influences of forest roads on the spatial patterns of human- and lightning-caused wildfire ignitions. - Applied Geography 32(2): 878-888.

[18] Pourtaghi, Z. S., Pourghasemi, H. R., Aretano, R., Semeraro, T. (2016): Investigation of general indicators influencing on forest fire and its susceptibility modeling using different data mining techniques. - Ecological Indicators 64: 72-84.

[19] San-Miguel-Ayanz, J., Schulte, E., Schmuck, G., Camia, A., Strobl, P., Liberta, G., McInerney, D. (2012): Comprehensive Monitoring of Wildfires in Europe: The European Forest Fire Information System (EFFIS). - In: Tiefenbacher, J. (ed.) Approaches to Managing Disaster. Assessing Hazards, Emergencies and Disaster Impacts. IntechOpen, London.

[20] Sukitpaneenit, M., Oanh, N. T. K. (2014): Satellite monitoring for carbon monoxide and particulate matter during forest fire episodes in Northern Thailand. - Environmental Monitoring and Assessment 186(4): 2495-2504.

[21] Suryabhagavan, K. V., Alemu, M., Balakrishnan, M. (2016): GIS-based multi-criteria decision analysis for forest fire susceptibility mapping: a case study in Harenna forest, southwestern Ethiopia. - Tropical Ecology 57(1): 33-43.

[22] Vinod, P. G., Ajin, R. S., Jacob, M. K. (2016): RS and GIS based spatial mapping of forest fires in Wayanad Wildlife Sanctuary, Wayanad, North Kerala, India. - Int. J. Earth Sci. Eng. 9: 498-502. 